\title{
An Appreciation for "I Wandered Lonely as a Cloud"
}

\author{
Suqin Liu \\ School of Foreign Languages \\ Huanghe Science and Technology College \\ Zhengzhou, China
}

\begin{abstract}
William Wordsworth, the representative poet of the early romanticism, is regarded as a "worshipper of nature", who can penetrate to the heart of things and give the reader the very life of nature. He wrote a lot of poems on nature. "I Wandered Lonely as a Cloud" is one of his famous short lyrics to show his deep love for nature. This paper focuses on talking about the background and appreciating of the beauty of the poem for its charming poetic language and the significance of it.
\end{abstract}

Keywords-Wordsworth; the daffodil; nature; metrical pattern; content

\section{INTRODUCTION}

William Wordsworth (1770-1850), together with Coleridge and Southey, are known as the "Lake Poets", because they lived in the lake district in the northwestern part of England. Wordsworth was initially a fervent supporter, but later one of the resolute opponents of the French Revolution and turned back to nature in search of the harmony between man and nature.

Wordsworth is the leading figure of the English romantic poetry, the most important contribution he has made is that he has not only started the modern poetry, the poetry of the growing inner self, but also changed the course of English poetry by using ordinary speech of the language and by advocating a return to nature. [6](P109) To him, nature acts as a substitute for imaginative and intellectual engagement with the development of embodied human beings in their diverse circumstances. It is nature that gives him "strength and knowledge full of peace." "I Wandered Lonely as a Cloud" is perhaps the most anthologized poem in English literature, and one that takes us to the core of Wordsworth's poetic beliefs. [11](P7)

\section{THE BACKGROUND TO WRITING "I WANDERED LONELY AS A CLOUD"}

William Wordsworth was born in a Northern England family, sound and healthy in his moral tone, and vigorous physically. Losing his parents early in life, he was left to the care of uncles who discharged their trust in a praise worthy manner. He went to school in his ninth year. These school days were happy ones. He boarded in the village with a kindly old dame, and out of school hours, he was free from the supervision of tutors. Just like he writes: "I was at liberty then, and in the vacation, to read whatever books I liked." $\mathrm{He}$ enjoyed the sports hunting, skating, and rowing. Little by little, the glories of nature grew upon him, until his soul seemed flooded with unutterable delight when in her presence.

It was just because of his rich life experiences that he had a long poetic career and turned out many volumes of poetry. In his poems, Wordsworth aimed at simplicity and purity of the language, fighting against the conventional forms of the 18th century poetry and described the simple rural folk whom the poet was familiar with as a result of his long stay in the Lake District. He sang of birds and plants of nature.

Wordsworth advocates that "all good poetry is the spontaneous overflow of powerful feeling, take its origin from emotion recollected in tranquility" and proposes to "choose incidents and situation from common life and to relate or describe them." [4] (P241-P242)

The inspiration of the poem was based on a tour of Wordsworth in the countryside, which was recorded by his sister Dorothy Wordsworth: "When we (the Wordsworths) were in the woods beyond Gowbarrow Park we saw a few daffodils close to the water-side ... a long belt of them along the shore... I never saw daffodils so beautiful. They grew among the mossy stones about and about them... seemed as if they verily laughed with the wind, that blew upon them over the lake; they looked so gay, ever glancing, ever changing." [3] (100) It was a great source of inspiration to Wordsworth, who relied on the natural impression of such fantastic scenery and his great imagination to write "I Wandered Lonely as a Cloud". Later, this lyric poetry was collected to the "Poems of the Imagination".

\section{THE BEAUTY OF "I W ANDERED LONELY AS A ClOUD"}

Poetry is the finest flower of literature. It is culminated form of literature, the apex of literature. Especially, poetical language is the loftiest and purest language, "the best words in their best order" (S.T.Coleridge). [5] (P6-P7) There are two ways to appreciate the beauty of language for "I Wandered Lonely as a Cloud".

\section{A. The Metrical Pattern}

English poetry is divided into lines, and these lines have some kind of rhythmic pattern. ... Such an underlying rhythmic pattern is called metre; and metrical patterns of some kind appear to be basic to all poetry. [1] (P6) It is measured mainly by foot and lines, which can give a sense of perfection, completeness and permanence. 
1) The iambic tetrameter pattern: Rhythm is expressed in alternation with regularity, which can create the feeling of beauty and pleasure. The line or verse is a larger integer or unit of poetry, as the foot is the smaller. In the poem, it contains four stanzas, each one has six lines.

Meter is measure. Foot is the unit of measurement in meter, blending of time interval and a group of syllables. The basic form of foot in "I Wandered Lonely as a Cloud" is the iambic meter, a disyllabic foot containing an unstressed syllable followed by a stressed one. For example:

I wandered lonely as a cloud

That floats on high o'er vales and hills,

Each line consists of a certain number of metrical feet, disposed according to some rule or design. The lengths of the line can be classified as short lines, the tetrameter, pentameter and so on. In "I Wandered Lonely as a Cloud", by scansion, the basic length is tetrameter, a line of four feet. Let's see another two lines :

When all at once I saw a crowd,

A host; of golden daffodils;

So, according to the explanation of the foot and line, the whole poem employs an iambic tetrameter metrical pattern.

2) The metrical mutation in the poem: Mutation, or variation, is the most important law of English prosody. If the whole poem follows one pattern without any variation, it must be monotonous and sounds dull. There will be no beauty pleased to the ears. And in "I Wandered Lonely as a Cloud", the dynamic state of daffodils in the wind can not well display to the reader. Therefore, the proper neat change makes the poem seem lively and rhythmical. In the sixth line of the first stanza.

Fluttering and dancing in the breeze.

There are only three stressed syllables equally appearing at the beginning, the middle and the end of the lines. It transfers the great surprise and excitement of the lonely poet to the reader, when he saw a cluster of daffodils at random. "Flutter" and "dance", stressed here, are to describe the movement of the daffodils swinging in the lightly wind. The change mood from solitude to pleasure is accurately expressed by the alternation of the rhyme. And in the sixth line of the second stanza:

Tossing their heads in sprightly dance.

This line begins with a trochee "Tossing", containing a stressed syllable followed by an unstressed. The trochee can give the reader a deep and lively expression. "Toss" means to move restlessly from side to side. The unexpected stressed word "tossing" is placed in the beginning, which can emphasize the dynamic state of the lovely daffodils and reinforce the expressive force of the lines, which is also the spontaneous overflow of the poet's strong emotion.

3) Two forms of mutation: Run-on lines and caesura are mostly used in this poem. No pause between the first and second lines reveals that the continuous idea is interrupted to fit the demand of the arrangement of the rhythm. That is the run-on lines which are seen when sense and syntax leap to the next line without a pause. The other is the caesura, which is a pause in the reading of a line of verse that does not affect the metrical account of the timing.[5](P304.P314)

The waves beside them danced; but they

Out-did the sparkling waves in glee:

A poet could not but be gay,

In such a jocund company:

I gazed - and gazed - but little thought

What wealth the show to me had brought:

The above is the third stanza of the poem. In "I Wandered Lonely as a Cloud", this variation can help the poet to express his strong feelings about the vivid picture of daffodils. They can slow down the quick rhythm and make the readers unconsciously take a pause to fully understand the strong feelings of the poet to the daffodils. Especially, in the fifth lines of this stanza, two dashes are used to prolong the time of vowel /ei/, which can make the reader to feel the attentiveness and euphoria of the poet to the beautiful flowers.

\section{B. The Sound Pattern in "I Wandered Lonely as a Cloud"}

Rhyme, a common feature of English poetry since the fourteenth century, can make the poem sound beauty to attain the unity and neat as a whole. It always is classified into end rhyme, internal rhyme. The end rhyme is common in poetry. It means the last word of a line has the same final sounds at the last word of another line.

In the poem, the form of the end rhyme is ababcc, efefgg, hihikk, lmlmnn. For example, in the first stanza, "cloud" and "crowd", "hills" and "daffodils", "trees" and "breeze", form a couple of rhyme to produce an intensity of rhythmic. It always sounds beautiful and mellifluent just like music, pleased to the ears.

The commonest rhymes in English poetry are so-called masculine ones, rhymes in which there are no unstressed syllables following the stressed ones (way/bay, lie/eye); but quite often we also find feminine ones, in which one unstressed syllable follows the stressed one (twinkle/Milky, pensive/inward),

Rhyme can increase our consciousness of the line-ending, and so reinforce the metrical pattern. A rhyme at the end of a sentence gives a sense of finality and completeness. [1] (P24)

The internal rhyme includes alliteration, assonance, and so on. Alliteration is the identicalness of initial consonants. For instance, "beside" and "beneath" emphasize the specific location of the daffodils, "stars" and "shine" presents the large number of it. All of them make the line be intensification of feelings. 


\section{THE CONTENT OF "I WANDERED LONELY AS A CLOUD"}

\section{A. The Main Ideas of the Poem}

Nature is the permanent and universal motif for the human being. "Poetry is the image of man and nature." The grandeur of nature soothed Wordsworth's soul.

In the first stanza, the poet, the first person narrator, walks outside and accidentally saw a cluster of beautiful daffodils. The second stanza, he vividly portrays the versatile poise of the full-blown daffodils. In these two stanzas, the poet emphasizes the external beauty of the fantastic scenery. In the third stanza, the poet is completely absorbed into the enchanting scene of the daffodils and feels the internal pleasure and excitement.

"It is necessary for the individual mind to cooperate with the external mind in Nature." [3] (P54) Therefore, in the last, also the most important stanza, is the reflection of the past scene. Whenever the poet feels lonely, senseless or absent, the image of the daffodils has a great influence on him, which makes him to be aware of "the bliss of solitude." Reclusion gives him full time of thinking and the understanding of the daffodils is up to the height of reason. Here, "bliss" means holy happiness, an extreme happiness of being with god. Therefore, nature to him is a source of mental cleanliness and spiritual understanding; it is a teacher; it is the stepping stone between Man and God. The free-grow flowers not only purify the soul of poet, but also to the reader.

\section{B. The Figure of Speech in the Poem}

The beauty of "I Wandered Lonely as a Cloud" also lies on the vivid description of the daffodils to satisfy the imagination of the readers. The poem uses different figurative devices to enhance the appealing and aesthetic effect.

In the first line, the poet employs the simile to compare himself as a cloud to wander in hills and vales. It fully shows the ease and leisure state of the poet. "Fluttering and dancing in the breeze" and "Tossing their heads in sprightly dance", personification is used here to describe the external beauty of the daffodils in a picturesque and visional sight. At the same time, the beautiful scene brings great pleasure to the poet himself. In the second stanza, simile and hyperbole are both used to draw a wonderful picture of daffodils. Those lines indicate flourishing vitality of the flowers and imply the poet's thirst for the value of life and the yearning for the wonderful life. "And dances with the daffodils" again makes use of personification to show that whenever the poet recalls the flowers, his heart must be full of pleasure and satisfaction. Thus, the daffodils become the spiritual consolation. The employment of the figure of speech, takes the reader to the scene of the daffodil.

\section{Reflection on Nature}

Here, we will say more about Wordsworth's poems about nature. He was a passionate lover of nature and his descriptions of lakes and rivers, of meadows and woods of skies and clouds are quite exquisite. Throughout his literary career especially in his early period, he frequently sang of birds and plants with much rapture and he also wrote lyrics to exalt nature as an important source of his inspiration. Wordsworth revealed his spontaneous joy in seeing and hearing these creatures of the animal kingdom, often with boyish enthusiasm.

In one of his later poems "I Wandered Lonely as a Cloud", he showed his joy at the sight of the beautiful daffodils but also reflected the philosophical of depth of his mind under the enchantment of nature. This is a poem full of the beauty of the nature and the feeling of the author. It can be divided into two parts: the first sixteen lines mainly describe the beauty of the daffodils, while the next eight lines mainly describe the author's surprising feelings upon seeing the host of golden daffodils. At the beginning of the poem, the author feels a little lost and gloomy, just like the foggy sky before the sunrise. In the presence of the daffodils, the author's heart becomes full of happiness and freedom, as well as the permanent daffodils. How can the cloud in the sky be lonely? Does it have any connection with the author? Perhaps he meets some difficulties or problems in life or work, or perhaps he is not in the mood, so he wanders about alone like a lonely cloud floating over deep valleys and high hills. Then the unexpected appearance of the daffodils fills the author with a completely different feeling. The author seems to forget the trouble troubling him temporarily, completely getting rid of all the inequality, sadness and misery. In the second stanza of the poem, the author continues to describe the wonderful picture of the dancing daffodils. The daffodils seem endless, stretching forward without stopping. Similarly, the author's surprise and happiness seems no end. He is absorbed into this happy world. In the third stanza, the author speaks highly of the current situation. He wants to further prove his point that anybody in this situation can not but be happy. In the fourth stanza, the author seems to come back to the reality. He thinks of the vacant and pensive moments in his life again.

\section{CONCLUSION}

Wordsworth is the closest to nature. He conceives nature as "The nurse, /The guide, the guardian of my heart, and soul/of all my moral being." In his view, the natural world is the dominant influence in changing people's sensibilities.[11] (P14)As he is aware of his own sublime communion with all things, nature becomes an inspiring force of rapture, a power that reveals the workings of the soul. "I Wandered Lonely as a Cloud" is well presented Wordsworth's principle of "spontaneous overflowing of powerful feeling." and the harmony between man and nature. Through twenty-four lines of "I Wandered Lonely as a Cloud", Wordsworth collects all the memory and imagination of the daffodils around the lake, and makes the soul tranquility. At the same time, the beautiful dancing daffodils in his memory must be an enduring image to the reader. In the poem, the author presents us many images, like cloud, flowers, lake, trees, breeze, the margin of the bay, sparkling waves, all of which give us a picture with various energetic living things in the nature.

\section{REFERENCES}

[1] Barber, Charles. Poetry in English, an Introduction, London: The MacMillan Press, LTD, 1983. 
[2] Leech, Geoffrey N. A Linguistic Guide to English Poetry, Beijing: Foreign Language Teaching and Research Press, 2001.10.

[3] Purkis John. A Preface to Wordsworth, Britain: Longman Group Ltd. 1970.

[4] The Norton Anthology of English Literature. Volume II : P239-P251.

[5] Wang Baotong. Round the realms of gold: A Poetry Textbook, Kaifeng: Henan University Press, 1993.5.

[6] Hao Fengjiao, Wordsworth and His Poety, Journal of Langfang Teachers College, 2002.9 P109-P111.

[7] Feng Cuihua, English Rhetorical Options, Beijing,Foreign language teaching and Research Press, 1995.

[8] Liu Bingshan,The History of English Literature,Zhengzhou, The people of Henan Press, 1993.4 P250_-P259.

[9] Ding Wangdao, Zhuqing, The Analysis of Good English Poetry,ShangHai, ShangHai Translation Press, 1989,12. P32-P60.

[10] Zhang Baixiang, The Course of English Literature,WuHan, WuHan University Press. 2006.1P7, P14.

[11] Lining ,An Analysis o f I Wandered Lonely as a Cloud by Using the Tenets of New Criticism, The Information of science. 